\title{
Response of Mytilus edulis to enhanced phytoplankton availability by controlled upwelling in an oligotrophic fjord
}

\author{
Strohmeier Tore ${ }^{1,{ }^{*}}$, Strand Øivind ${ }^{1}$, Alunno-Bruscia Marianne ${ }^{1,2}$, Duinker Arne ${ }^{3}$, Rosland Rune ${ }^{4}$, \\ Aure Jan ${ }^{1}$, Erga Svein Rune ${ }^{4}$, Naustvoll Lars ${ }^{5}$, Jansen Henrice ${ }^{1,6}$, Cranford Peter J. ${ }^{7}$
}

${ }^{1}$ Institute of Marine Research, PO Box 1870 Nordnes, 5817 Bergen, Norway

2 Ifremer, UMR 6539, 11 Presqu'île du Vivier, 29840 Argenton-en-Landunvez, France

${ }^{3}$ National Institute of Nutrition and Seafood Research, PO Box 2029 Nordnes, 5817 Bergen, Norway

${ }_{5}^{4}$ University of Bergen, Dept of Biology, PO Box 7803, 5020, Norway

${ }^{5}$ Institute of Marine Research, Nye Flødevig veien 20, 4817 His, Norway

${ }^{6}$ Institute for Marine Resources and Ecosystem Studies (IMARES), PO Box 77, 4400 AB Yerseke, The Netherlands.

${ }^{7}$ Fisheries and Oceans Canada, Bedford Institute of Oceanography, Dartmouth, Nova Scotia, Canada

* Corresponding author : Tore Strohmeier, email address : tore.strohmeier@imr.no

\begin{abstract}
:
The controlled upwelling of nutrient-rich deep water in oligotrophic coastal regions has been proposed as a means of increasing phytoplankton and, subsequently, bivalve aquaculture production. This was tested as part of a large-scale upwelling experiment in an oligotrophic environment (Lysefjord, Norway). The mean chlorophyll a concentration in the upwelling area was consistently higher than at the control

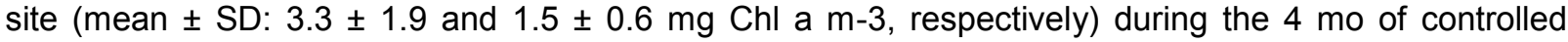
upwelling. After 2 mo with upwelling, the dry flesh weight of $1 \mathrm{yr}$-old and $2 \mathrm{yr}$-old mussels was $95 \%$ and $24 \%$ higher, respectively, than that of the mussels at the control site. The $1 \mathrm{yr}$-old mussels at the upwelling site achieved up to 2.4-fold higher dry flesh weight compared to the control. Reproductive output was also higher at the upwelling site and only there, spawning of $1 \mathrm{yr}$-old mussels was detected. Standardized clearance and respiration rates showed maximum values during the most intense period of tissue growth. Average ingestion rates were $40 \%$ higher at the upwelling than the control site. Tissue growth and clearance rates were not correlated with the measured seston parameters, suggesting that food acquisition was responsive to other exogenous parameters and/or to increased endogenous energy demands. It was concluded that the sustained upwelling of nutrient-rich deep water in an oligotrophic fjord can increase phytoplankton biomass, resulting in improved mussel growth performance and increased aquaculture production carrying capacity. Thus, controlled upwelling represents a simple but effective ecosystem engineering approach for enhancing human food production.
\end{abstract}

Keywords: Bivalve aquaculture, production carrying capacity, physiology, fjord ecosystems, shell growth, tissue growth 


\section{Introduction}

Bivalve aquaculture is typically most productive in regions where the seawater is rich in nutrients, such as at natural upwelling sites (Pitcher \& Calder 1998, Figueiras et al. 2002, Alvarez-Salgado et al. 2008) and where anthropogenic nutrient runoff causes eutrophic conditions (Saxby 2002). These nutrient-rich sites sustain the high phytoplankton concentrations needed to support high growth rates in dense populations of suspension feeding bivalves, and are valuable places to aquaculture and production of human food. Access to productive coastal areas is, however, limited due to conflicts on use of space. The demand for more marine human food resources has stimulated initiatives for aquaculture development even within oligotrophic environments. Despite chronic low food availability, these environments supports many economically-important bivalve species (Pouvreau et al. 1999, Yukihira et al. 1999, Sara \& Pusceddu 2008, Strohmeier et al. 2009).

The Norwegian coast comprise an enormous physical carrying capacity for aquaculture, yet the bivalve production carrying capacity (i.e. the cultured biomass and/or growth rate that can be sustained by available food) in most fjords is expected to be low(Aure et al. 2001, Andersen et al. 2014). Most Norwegian fjords are oligotrophic as a result of nutrient limitation in the euphotic zone during summer (Paasche \& Erga 1988). Stratification between the upper brackish layer and the nutrient-rich intermediate layer 
67 segregates the euphotic zone from the deeper nutrient-rich water for extended periods of 68 the year(Erga et al. 2005, Erga et al. 2012) and plays an important role in regulating 69 pelagic primary production and the vertical distribution of phytoplankton (Erga \& 70 Heimdal 1984, Erga 1989a, b, Erga \& Skjoldal 1990, Erga et al. 2005). In most fjords the 71 chlorophyll $a(\mathrm{Chl} a)$ concentration is low $\left(0.5\right.$ to $\left.2 \mathrm{mg} \mathrm{m}^{-3}\right)$ during most of the growth 72 season of blue mussels (Mytilus edulis). Depletion of seston by farmed mussels has been 73 shown to influence their growth performance, physiology and the production carrying 74 capacity (Strohmeier et al. 2005, Aure et al. 2007b, Strohmeier et al. 2008, Rosland et al. 75 2009, Strohmeier et al. 2009, Rosland et al. 2011). The development of a bivalve farming 76 industry in Norway, currently at a level of 2000 metric tons of mussels, involves 77 knowledge on production carrying capacity in an oligotrophic environment. The use of 78 controlled upwelling of nutrient-rich deep water in fjords (Aure et al 2007a) represents a 79 measure to enhance such capacity and is considered to be one of the most promising 80 ways to increase seafood production in a sustainable manner (Andersen et al. 2014).

82 To enhance primary production in Lysefjord, an oligotrophic mussel cultivation area in 83 Norway, a large-scale upwelling experiment was initially conducted during the summers 84 in 2004 and 2005 (Aure et al. 2007a). Forcing brackish surface water (at a rate of $2 \mathrm{~m}^{3} \mathrm{~s}^{-}$

$85^{1}$ ) to a depth of $30 \mathrm{~m}$ created an upwelling of nutrient-rich deep water into the euphotic 86 zone. This upwelling approximately tripled the mean $\mathrm{Chl} a$ concentration within an area 87 of $10 \mathrm{~km}^{2}$. The increased phytoplankton concentration due to controlled upwelling was 88 within the natural variability of the fjord ecosystem and confined to the area of interest. A 89 multiple box ecosystem model showed carrying capacity scenarios of mussel farming in 90 the inner influenced regions of Lysefjord taking into account stocking densities, 91 upwelling alternatives, and the cultivation areas(Filgueira et al. 2010). A higher and 92 stable concentration of phytoplankton, dominated by non-toxic species is likely to 93 increase the fjords carrying capacity of suspension feeders and could form the basis of 94 more predictable mussel cultivation in oligotrophic environments. The objective of the 95 present study was to test the hypothesis that controlled upwelling could significantly 96 improve dietary conditions and blue mussel growth performance within an upwelling 97 area in the Lysefjord. A secondary objective was to determine the feeding response of 
Growth of Mytilus edulis

98 mussels to the changes in dietary conditions resulting from upwelling to further improve

99 our understanding of mussel feeding strategies and the physiological control of growth.

100

101 Suspension feeding bivalves are often exposed to a natural diet that is highly variable in

102 terms of availability and composition. The functional feeding response of bivalves is

103 known to be responsive to dietary conditions and food acquisition is primarily determined

104 by the ability of suspension feeding bivalves to control clearance rate (Hawkins et al.

105 1999, Gardner \& Thompson 2001, Hawkins et al. 2001, Cranford et al. 2005, Strohmeier

106 et al. 2009, Cranford et al. 2011). Bivalves may also increase the nutritional value of the

107 ambient seston by altering particle retention efficiency(Strohmeier et al. 2012), by

108 preferentially capturing particles on the gills, and/or by selectively rejecting particles as

109 pseudofaeces (Ward \& Shumway 2004). The vast literature on the capacity of bivalves to

110 alter feeding processes in response to natural diet variability (reviewed by Cranford et al.

111 2011, Ward and Shumway 2004) opposes the view that feeding is a simple function of

112 diet saturation reduction and valve closure (Riisgard et al. 2013). The latter theory is

113 based exclusively on evidence from laboratory feeding studies with an artificial diet

114 designed to stimulate maximal clearance rate (Riisgard 2001, Riisgard et al. 2013).

115 Consequently, this viewpoint and the related methodology are not widely accepted

116 (Bayne 1998, 2001, Cranford 2001, Widdows 2001, Cranford et al. 2011). Elucidating

117 the feeding strategies of bivalves under natural systems remains as an active field of

118 research partly because no clear relationships have been found between the seasonal

119 variations in feeding activity and many potential environmental forcing functions

120 (Cranford \& Hill 1999, Strohmeier et al. 2009). Functional feeding responses are also

121 needed to improve the accuracy of model-based assessments of the carrying capacity of

122 different sites for bivalve aquaculture (e.g. Filgueira et al. 2010).

\section{Material and Methods}

126 Blue mussel (M. edulis) shell and tissue growth and physiological responses were 127 investigated between March and December 2010 in Lysefjord, Norway (Fig. 1). 


\section{Growth of Mytilus edulis}

128 Lysefjord is approximately $40 \mathrm{~km}$ long and 0.5 to $2 \mathrm{~km}$ wide, with a maximum depth of 129460 meters, a mean tidal range of $0.4 \mathrm{~m}$, and a surface area of $44 \mathrm{~km}^{2}$. The fjord has a 14 $130 \mathrm{~m}$ deep sill at the entrance. At the forced upwelling site, situated near the head of the 131 fjord (Fig. 1; N 59 03'22', E $6^{\circ} 37^{\prime} 75^{\prime}$ '), a pump was used to force brackish water 132 through a pipe, at a rate of approximate 0.7 to $0.9 \mathrm{~m}^{3} \mathrm{~s}^{-1}$, down to a depth of $30 \mathrm{~m}$, where

133 it dispersed into the surrounding nutrient-rich deep water. We used the same upwelling

134 platform as Aure et al. (2007a). The pump was started on the $27^{\text {th }}$ of April and shut down

135 on the $20^{\text {th }}$ of August, 2010. The ascending plume of nutrient-rich water has been 136 estimated to rise at a rate of $\sim 10$ to $15 \mathrm{~m}^{3} \mathrm{~s}^{-1}$ to an intrusion depth of 6 to $10 \mathrm{~m}$, based on 137 Aure et al. (2007a). At present the upwelling is forced by gravity, and there are low 138 operational costs linked to the upwelling.

140 Mussel growth performance and environmental factors were measured within the 141 upwelling area near the head of the fjord (UPW site) and at a control (CONTR) site 142 located $14 \mathrm{~km}$ outside the UPW site.

\section{Experimental bivalves}

145 The cohorts of M. edulis used in experiments were collected in March 2010 from 146 suspended ropes in the Lysefjord. To ensure that the mussels were from known cohorts, 147 they were collected from separate ropes that had been stocked as juveniles in 2008 and 148 2009. On each collection occasion, each cohort was graded to a narrow range of shell 149 length. The 2008 (two-year-old mussels, mean shell length $47 \mathrm{~mm}$, SD 1.3) and 2009 150 (one-year-old mussels, mean shell length $18 \mathrm{~mm}$, SD 0.9) cohorts were divided into 151 groups of 40 individuals, which were individually marked for later identification and 152 transferred, on the $3^{\text {rd }}$ of March 2010, to the UPW and CONTR sites. The marked mussels 153 were used to follow individual increases in shell length (measured, by a digital calliper, 154 from umbo to posterior edge, $\pm 0.01 \mathrm{~mm}$ ). An additional 800-900 graded mussels from 155 each of the above cohorts were divided between the two sites and used to follow temporal 156 changes in dry flesh weight (DFW). On each sampling occasion, DFW was determined $157( \pm 0.01 \mathrm{~g})$ for approximately 20 mussels by freeze-drying the tissue. The mussels were 158 suspended from a single long-line, perpendicular to the current direction, in one meter 
Growth of Mytilus edulis

159 long lantern netsat $7 \mathrm{~m}$ depth, at the experimental sites. Stocking density was

160 approximately40 individuals per dish (80 individuals per $\mathrm{m}^{2}$ ). The shell length and DFW

161 of mussels was monitored on a bi-weekly or monthly basis, from March to December

162 2010.The lantern nets were cleaned of fouling on each sampling date.

\section{Environmental parameters}

165 Temperature, salinity and fluorescence were simultaneously measured at both sites, at 30 166 min intervals and at a depth of $7 \mathrm{~m}$, using STD/CTD 204 instruments (SAIV A/S, 167 Norway). The optical surface of the fluorometer was cleaned every second week.

168 The STD/CTD instrument located at the UPW site was also used to profile the water 169 column at both stations down to 30 meter depth on eight occasions between April and 170 August. For profiling, the instrument was set to $\log$ at $1 \mathrm{~Hz}$ and lowered at approximately $171 \quad 0.2-0.4 \mathrm{~m} \mathrm{~s}^{-1}$. Data from both down and up-cast has been used.

173 Fluorescence units were converted to chlorophyll $a(\mathrm{Chl} a)$ concentrations, based on the 174 results of discrete water sample analysis at the study sites. Water samples $(1.5 \mathrm{~L})$ for 175 seston concentration and organic content analysis were collected from seven meters 176 depth, usually on a fortnightly basis. Suspended particulate matter, particulate organic 177 matter, and particulate inorganic matter (SPM, POM, and PIM respectively; $\mathrm{mg} \mathrm{L}^{-1}$ ) were 178 determined in triplicate for seston filtered onto pre-ashed and tared $1.2 \mu \mathrm{m}$ nominal pore179 size filters (Whatman GF/C). Salt was expelled from SPM samples by rinsing each filter 180 under vacuum with isotonic ammonium formate. Filters were then dried at $60^{\circ} \mathrm{C}$ 181 overnight and weighed, to determine SPM. The SPM samples were then heated to $450^{\circ} \mathrm{C}$ 182 and reweighed, to determine POM and PIM.

184 Samples for the determination of $\mathrm{Chl} a$, particulate organic carbon (POC) and particulate 185 organic nitrogen (PON) were collected simultaneously(for all parameters $\mathrm{N}=1$ ), as SPM 186 samples, by filtering seston $(0.50 \mathrm{~L})$ onto a $1.2 \mu \mathrm{m}$ filter (Whatman GF/C). Chl $a$ was 187 analysed after extraction with $90 \%$ acetone using the fluorescence method, corrected for 188 acidified measurements (Strickland \& Parson 1968). The fluorometer (Turner Designs 189 Model 10-AU) was calibrated with known concentrations of Chl $a$ (Sigma Chemicals, St. 
Growth of Mytilus edulis

190 Louis, Mo., USA) and measured, using a spectrophotometer. Fluorescent 191 measurements(x) obtained by the two fluorometers were converted to Chl $a$ concentration 192 using the following equations:

1932010 UPW site; $\operatorname{mg~Chl~} a \mathrm{~m}^{-3}=1.31 \mathrm{x}-0.11 ;\left(\mathrm{r}^{2}=0.96, \mathrm{n}=8\right)$

1942010 CONTR site; $\operatorname{mg~Chl~} a \mathrm{~m}^{-3}=0.32 \mathrm{x}+0.46 ;\left(\mathrm{r}^{2}=0.42, \mathrm{n}=8\right)$

195 The latter correlation was relatively low due to the limited range of Chl concentrations 196 measured at the control site.

198 POC and PON were determined using a Thermo Finnigan FlashEA 1112 NC Analyzer 199 after drying and fuming the filters over concentrated $\mathrm{HCl}$ for $0.5 \mathrm{~h}$ in a closed container 200 to remove inorganic carbon.On each sampling occasion, the number and volume 201 concentration of suspended particles, within 30 size-intervals between 1 and $60 \mu \mathrm{m}$ 202 diameter, were determined by a laser particle counter (PAMAS GmbH, Model S4031GO, 203 Germany). In calculating particle volume (PV) we assumed that particles were spherical.

\section{Determination of clearance rate}

206 A time-series of average shell length standardized clearance rate $\left(C, \mathrm{~L} \mathrm{~h}^{-1}\right)$ measurements 207 was determined at the UPW and CONTR sites, from the 2008 cohort using natural 208 seawater pumped from a depth of $7 \mathrm{~m}$. All $C$ measurements were obtained using the same 209 flow-through method, feeding chambers and protocols as previously reported in 210 Strohmeier et al. $(2009,2012)$. The internal dimensions of the mussel chambers were 3.8 $211 \mathrm{~cm}$ wide $\times 19.5 \mathrm{~cm}$ long $\times 8.1 \mathrm{~cm}$ height. This chamber design restrains recirculation and 212 therefore helps to prevent re-filtration of water by the bivalves. Flow rates into each 213 chamber were carefully controlled to exceed values known to allow water recirculation 214 and re-filtration (Strohmeier et al. 2009).

216 On each biweekly or monthly sampling date, 20 marked mussels were temporarily 217 transferred from the lantern nets to individual feeding chambers that were then left 218 undisturbed in flowing seawater for at least $0.5 \mathrm{~h}$, so that feeding was resumedprior to 219 water sampling from the outlet of the chambers. Two additional chambers were left 


\section{Growth of Mytilus edulis}

220 empty, to serve as controls. The water samples were analysed for particle concentration using the laser particle counter described above. $C$ was calculated as

$$
C=R E * F,
$$

223 where $F$ is the flow rate $\left(\mathrm{L} \mathrm{h}^{-1}\right)$ measured at the outlet of each chamber, and $R E$ is the

224 particle retention efficiency, calculated as

$$
R E=\left(P V_{C}-P V_{B}\right) / P V_{C},
$$

226 where $P V_{C}$ is the mean particle volume $\left(\mathrm{mm}^{3} \mathrm{~L}^{-1}\right)$ exiting the control chambers, and $P V_{B}$

227 is the particle volume exiting the bivalve chamber. $F$ was typically $11-14 \mathrm{~L} \mathrm{~h}^{-1}$, giving

228 estimated current speeds in chambers of between 0.2 and $0.3 \mathrm{~cm} \mathrm{~s}^{-1}$. These flow rates

229 were selected on the basis of initial observations to prevent $C$ results from being

230 underestimated by water refiltration at insufficient flow. For the calculation of $C$ it was

231 assumed that the maximum particle retention efficiency occurs across the 4 to $30 \mu \mathrm{m}$

232 particle size range. Each chamber was carefully examined for pseudofaeces production,

233 which was absent at both stations throughout the study period.

235 Individual clearance rates were standardized to an equivalent individual of $50 \mathrm{~mm}$ shell

236 length,using the following equation:

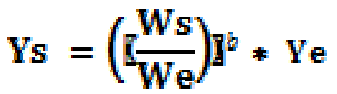

238 where $\mathrm{Y}_{\mathrm{s}}$ is the standardised parameter ( $C$ of a $50 \mathrm{~mm}$ mussel), $\mathrm{W}_{\mathrm{s}}$ is the standardised

239 shell length, $\mathrm{W}_{\mathrm{e}}$ is the shell length of the mussel, $\mathrm{Y}_{\mathrm{e}}$ is the mean measured $C$ and $b$ is the

240 mean allometric exponent. A $b$ value of 2.092 was chosen for mussels (Jones et al. 1992,

241 Filgueira et al. 2008).C was standardized to shell length instead of dry flesh weight owing

242 to the potential confounding effects of any differences in mussel condition index at the

243 two study sites (reviewed by Cranford et al. 2011).

\section{Respiration rate}

246 A time-series of average standardised (dry flesh weight) respiration rate $\left(R, \mathrm{mg} \mathrm{O}_{2} \mathrm{~g}^{-1} \mathrm{~h}^{-}\right.$

$24{ }^{1}{ }^{1}$ )measurements was determined at the UPW and CONTR sites for the 2008 cohort using

248 individual incubation chambers $(0.4 \mathrm{~L})$ supplied with natural seawater pumped from a

249 depth of $7 \mathrm{~m}$. These measurements were conducted on 10 of the 20 individually-marked 


\section{Growth of Mytilus edulis}

250 M. edulis used for the $C$ measurements. To maintain ambient temperature during the experiment, the incubation chambers were placed in a water bath supplied by flowing sea water from a seven meter depth. The mussels were held in the chambers with flowing water for at least 30 minutes, at which time all flow into the chambers was terminated

254 and the incubation started. Oxygen concentration and temperature in the experimental 255 chambers was measured, at the beginning and end of each experiment, with an oxygen 256 optode (Aanderaa Data Instruments, Mod. 3835, Norway). We varied the incubation 257 period (which ranged from 0.5 to $1.5 \mathrm{~h}$ ) according to the ambient water temperature, so as 258 to limit the oxygen decrease, to levels not higher than approximately $20 \%$ of the initial 259 concentration. One chamber remained empty, as a control for any non-bivalve effects on 260 the oxygen concentration, over the incubation period.

261 The respiration rate was calculated as:

$$
R=\frac{(\mathbf{A}-\mathbf{B}) * \mathbf{V}}{t}
$$

263 where $R$ is the respiration rate $\left(\mathrm{mg} \mathrm{O}_{2} \mathrm{~h}^{-1}\right)$, A and $\mathrm{B}$ are oxygen concentrations $\left(\mathrm{mg} \mathrm{O}_{2} \mathrm{~L}^{-}\right.$

$264^{1}$ ) at the start and at the end of the experiment, respectively, $\mathrm{V}$ is the volume of the 265 chamber (excluding the bivalve volume, in litres), and $t$ is the elapsed time expressed in 266 hours. $R$ was corrected to account for differences between initial and end values of 267 oxygen concentration in the control chamber.

269 All respiration rates were standardized to an equivalent individual of $1 \mathrm{~g}$ DFW as 270 follows:

$$
\left.\mathbf{Y s}=\left(\frac{W s}{W e}\right)\right]^{b}+Y_{e}
$$

272 where $\mathrm{Y}_{\mathrm{s}}$ is the standardised parameter, $\mathrm{W}_{\mathrm{s}}$ is the standardised DFW, $\mathrm{W}_{\mathrm{e}}$ is the DFW of 273 the experimental animals, $\mathrm{Y}_{\mathrm{e}}$ is the mean measured $\mathrm{R}$, and $b$ is the allometric exponent, 274 which was set to 0.7 , according to(Smaal et al. 1997).

\section{Calculations and statistics}

277 Any significant differences in the mean annual seston quantity (Chl $a$, PV, SPM and 278 POC)and quality(POM\% and C:N)at the UPW and CONTR sites were tested using $t$ 279 tests. Repeated-measures ANOVA were used to test for sampling site and date 


\section{Growth of Mytilus edulis}

280 differences in mean shell length, $C$ and $R$. Prior to each statistical test, homogeneity of

281 variance was evaluated using Greenhouse-Geisser's and Huynh-Feldt epsilon indices for 282 repeated measures (Latour \& Miniard 1983). Two way ANOVA was used to test for 283 differences in DFW in the group of mussels from each site,at different sampling dates 284 and between the two sites. Cases of a significant ANOVA result were followed by a 285 Tukey HSD post hoc test, when relevant(Zar 1996).Environmental and seston variables 286 relating to mussel growth, $C$ and $R$ were identified from a Pearson correlation matrix. 287 Statistical tests were performed at $\alpha=0.05$ with Statistica Version 11.1 (StatSoft, Inc 288 2012).

\section{Results}

\section{Environmental parameters}

292 Brackish water (psu < 25) was typically found in the upper 5 meter at both sites (Fig. 2). 293 The surface layer at the upwelling site showed relatively low saline water in May, 294 corresponding to the melting of snow in the highland and increased freshwater runoff 295 mixing with the underlying water outward the fjord. The mean salinity and temperature at 296 the holding depth of the mussels (7 m) was 27.8and 29.7 psu and 11.7 and $12.3{ }^{\circ}$ Cat the 297 UPW and CONTR sites, respectively. The temperature at the CONTR station tends to 298 increase about about14 days earlier than at UPW (Fig. 2). The Chl $a$ concentration at the 299 UPW site showed typically higher values at the intrusion layer (6 to $10 \mathrm{~m}$ depth) 300 compared to the CONTR station (Fig. 2).

302 The mean concentrations of Chl $a$ (Table 1), at the holding depth of the mussels at the 303 UPW site, was significantly higher than those at the CONTR site for both the water 304 samples ( $t$-tests, $\mathrm{df}=14, p=0.017$, F-ratio $=10.4, p=0.006$ ) and for the continuous 305 measurements ( $t$-tests, $\mathrm{df}=10373, p=0.001$, F-ratio $=9.3, p=0.001)$. The temporal 306 variation in Chl $a$ concentration at the depth of the mussels $(7 \mathrm{~m})$ shows the largest 307 differences between the UPW and CONTR sites from mid-May to mid-July, with the 308 concentration at the UPW site being two-three times higher than at the CONTR site (Fig. 309 3). Mean annual seston concentrations of PV, SPM and POC indicated that the highest 


\section{Growth of Mytilus edulis}

310 values were recorded at the upwelling site (Table 1, Fig 4) but the differences between

311 sites were not significant ( $t$-tests; $p>0.05$ ).

313 The nutritional quality of the seston, as indicated by the mean annual organic fraction

314 (POM\%)ranged between 54 and 59\% (Table 1) and there was no significant difference

315 between the two stations ( $t$-test; $p>0.05$ ). The $\mathrm{C}: \mathrm{N}$ molar ratio, another measure of diet

316 quality, indicated mean values ranging between 5.9 and 7.0 (Table 1)with minimum and

317 maximum values of 2.0 to 13.9 , respectively(Fig. 4). The highest C:N (lowest food

318 quality) was detected in late summer (Fig. 4). In summary, mussel food quantity, as

319 indicated by the Chl $a$ concentration, was significantly enhanced at the upwelling site

320 compared to the control, and this enhancement was most prominent throughout mid-May

321 to mid-July. The physical properties of the water column (temperature and salinity) and

322 indicators of the nutritional quality (for consumers) of the seston were, however, similar

323 between stations. Temporal variations in food quality indicators indicate relatively stable

324 levels throughout much of the year.

\section{Mussel shell growth}

327 The effect of location (UPW vs CONTR) on mean shell length was significant for both 328 cohorts and this effect was dependent on the sampling date for both cohorts (Table 2). At 329 the end of the upwelling period and at the end of the experiment the shell length was 330 significant higher at the UPW site for the 2008 cohort, but not for the 2009 cohort (Table 3312 and Fig. 5). The differences in shell length comprised only a few $\mathrm{mm}$. The estimated 332 daily shell growth rate was highest for the 2009 cohorts(Fig. 6). The highest daily shell 333 growth in the 2008 cohorts was obtained in July at the UPW site at $60 \mu \mathrm{m} \mathrm{d}^{-1}$. High daily

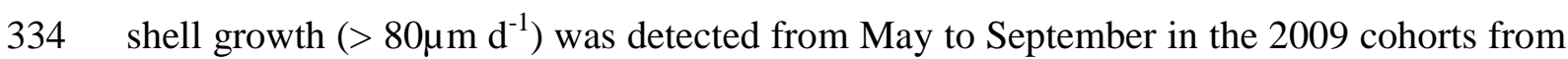
335 both sites. Shell growth rate was not positively correlated with any of the seston 336 parameters measured $(p>0.05)$. 


\section{Growth of Mytilus edulis}

\section{Mussel dry flesh growth}

The effect of location (UPW vs CONTR) on mean dry flesh weight was significant for both cohorts (ANOVA both cohorts, $p<0.001$ ), and this overall effect was dependent on the sampling date (ANOVA both cohorts, $p<0.001$ ). The temporal changes in DFW were distinct in both cohorts (Figs. 7 and 8). The main site-specific differences in DFW occurred in the last two weeks in June, when the mass of the 2009 cohort at the UPW site increased by almost three times, while the CONTR mussels showed only minor changes (Fig. 7). The mean daily growth rate in this period was $15 \mathrm{mg} \mathrm{DFW} \mathrm{d}^{-1}$, and is by far the highest growth rate detected for the 2009 cohort during the experiment (Fig. 8). The $46 \%$ drop in DFW mass from late July to August indicated that these mussels spawned. Spawning was not indicated for the 2009 cohort at the CONTR site. The highest DFW growth rates by the 2008 cohorts(UPW $=32$ and CONTR $=15 \mathrm{mg} \mathrm{d}^{-1}$ ) corresponded in time with the rapid DFW growth of the 2009 cohort in mid-June, and occurred after a spawning period in both the 2008 cohorts. The DFW lost during spawning (i.e. reproductive output) was larger at the UPW site $(0.31$ and $0.19 \mathrm{mg})$ compared to that in the CONTR site $(0.22$ and $0 \mathrm{mg})$ for the 2008 and 2009 cohorts, respectively. Weight recovery after spawning was fastest at the UPW site (Fig. 7). The mean difference in DFW after two months with upwelling was 24 and 95\% higher at the UPW site for the 2008 and 2009 cohorts, respectively (calculated from data shown in Fig. 7).The cumulative DFW growth enhancement at the UPW site, relative to the CONTR, was actually larger, as the above calculation does not account for the greater reproductive output and subsequent tissue mass recovery (Fig. 7).

Temporal variations in mean daily dry tissue growth rate for 2008 cohorts show two distinct periods of rapid growth (Fig. 8); negative growth (spawning) in late May followed by positive growth in June. The magnitude of both growth patterns was largest at the UPW site. Rapid daily growth rates in the 2009 cohorts were only detected at the UPW site. The timing of positive growth corresponded with the 2008 cohorts, and was similar in magnitude to the 2008 cohort at the CONTR site $\left(15 \mathrm{mg} \mathrm{DFW} \mathrm{d}^{-1}\right)$. The DFW growth rate did not positively correlate with any of the seston parameters measured $(p>$ $0.05)$. 


\section{Clearance rate}

371 The length-standardized clearance rate $\left(C\right.$ )of mussels at the UPW site averaged $2.8 \mathrm{~L} \mathrm{~h}^{-1}$, 372 and this value was significantly lower than the $3.5 \mathrm{~L} \mathrm{~h}^{-1}$ average determined for mussels at 373 the CONTR site (Table 2). $C$ ranged from 1.2 to 5.0 and 2.2 to $5.2 \mathrm{~L} \mathrm{~h}^{-1}$, respectively, at 374 the UPW and CONTR sites and the sampling date factor had a significant effect on 375 differences in mean $C$ between the two sites (Table 2 and Fig. 9). The highest $C$ values 376 were obtained in late June corresponding to the period of highest DFW growth (Fig. 7).

377 The mean ingestion rate of $\mathrm{Chl} a(C \times \mathrm{Chl} a)$ was 7.8 and $4.7 \mu \mathrm{g} \mathrm{Chl} a \mathrm{~h}^{-1}$ at the UPW and 378 CONTR site, respectively. Average $C$ values measured on each sampling date were not 379 significant correlated with temperature, salinity or any of the measured seston 380 parameters. Negative relationships (possibly non-linear) may, however, exist for some of 381 the food quantity variables. For example, the mean Cat Chl $a$ concentration $>3 \mathrm{mg} \mathrm{m}^{-}$ $382{ }^{3}$ was 30 to $40 \%$ less than the average value at lower food concentrations.

\section{Respiration rate}

385 There was no significant difference in the mean weight standardized respiration rate $(R)$ 386 measured at the UPW and the CONTR sites (Table 2). Mean Rwas0.95 and $0.96 \mathrm{mg} \mathrm{O}_{2} \mathrm{~h}^{-}$

$387{ }^{1} \mathrm{~g}^{-1}$ at the UPW site and at the CONTR site, respectively. Although temporal patterns in $R$ 388 between the sites were found to be significantly different (Table 2), respiration levels at 389 both sites peaked in mid-June (Fig. 9). The peak respiration rate in June corresponded to 390 a late phase of spawning or the initiation of rapid DFW growth (Figs. 7 and 8) and 391 increased $C$ (Fig. 9). $R$ was linearly correlated with particle volume ( $\mathrm{r}=0.71, p<0.004)$, 392 phaeopigment concentration $(\mathrm{r}=0.64, p<0.014)$, suspended particulate matter 393 concentration $(\mathrm{r}=0.60, p<0.029)$ and particulate organic matter concentration $(\mathrm{r}=0.57$, $394 p<0.047)$, but notto temperatureor salinity.

\section{Discussion}

397 The results of this study show that controlled upwelling in a stratified oligotrophic 398 environment can significantly increase phytoplankton biomass. Although upwelling was 


\section{Growth of Mytilus edulis}

399 limited to a four month period in the present study, it resulted in a significant

400 enhancement of blue mussel growth performance over the mussel growth period. This

401 demonstrates that anthropogenic enhancement of bivalve dietary conditions may facilitate

402 cultivation of bivalves in oligotrophic environments that have previously been considered

403 to be of limited use for human food production. Phytoplankton biomass at the upwelling

404 station in Lysefjord approximately doubled as a result of the upwelling of nutrient-rich

405 water. This is in accordance with previous studies in Lysefjord that showedapproximately

406 tripled phytoplankton concentration(Aure et al. 2007a). The lower response to the

407 upwelling of nutrient rich deep water in the present study is likely due to a lower

408 pumping rate of brackish water to force the upwelling, estimated at 0.7 to $0.9 \mathrm{~m}^{3} \mathrm{~s}^{-1}$

409 compared to the $2 \mathrm{~m}^{3} \mathrm{~s}^{-1}$ used in the study by Aure et al. (2007a). The differences in

410 chlorophyll $a$ concentration between stations disappeared as the pump was shut down in

411 August.

412

413 The enhanced tissue growth at the upwelling site compared to the control site resulted in

414 24(2008 cohort)to 95\%(2009 cohort) higher tissue mass after two months of upwelling.

415 Since these values do not include weight loss through spawning and, since reproductive

416 output was greater at the upwelling site, the cumulative growth enhancement at the

417 upwelling site was underestimated. As an example of maximal differences; harvesting

418 one year old mussels from the upwelling site in mid-July (before spawning) would result

419 in 2.4 times more DFW compared to the control site(Fig. 7). The present study is the first

420 to demonstrate how enhanced phytoplankton biomass, driven by controlled upwelling of

421 naturally abundant and composition of nutrients, can improve mussel growth

422 performance.Enhanced phytoplankton concentrations by forced upwelling may also

423 affect other grazers and higher trophic levels in coastal ecosystem (Yanagi \& Nakajima

424 1991, Jeong et al. 2013).

425

426 The observed changes in tissue mass between sampling dates provides information on

427 both somatic and reproductive tissue growth. We assume that $\operatorname{rapid}(<2$ weeks $)$ and large 428 decreases (exceeding the DFW loss during winter starvation,> 1-4 $\mathrm{mg} \mathrm{d}^{-1}$, (Strohmeier

429 2009)in mean dry flesh weight represents spawning. Temporal variations in tissue growth 


\section{Growth of Mytilus edulis}

430 were typically positive through most the year, except during spawning periods. Tissue

431 growth rate was highest in the pre-spawning period for the 2009 cohort at the upwelling

432 site and in the post-spawning period for both the 2008 cohorts, and probably coincided

433 with gametogenesis. The rapid building of tissue mass during post-spawning periods

434 occurred at both sites for the 2008 cohorts, yet the magnitude of tissue increase before

435 spawning, the reproductive output (weight loss as gametes), and the recovery rate, was

436 larger in mussels at the upwelling site. It is also notable that the one-year-old mussels at

437 the upwelling site went through gametogenesis and spawned while the mussels at the

438 control site showed no signs of gametogenesis and did not spawn. The greater availability

439 of phytoplankton at the upwelling site, particularly from mid-May to mid-July, is the

440 apparent cause ofenhanced tissue growth, reproductive output, and meat yield in thetwo

441 mussel cohorts situated inside the upwelling region of Lysefjord.

443 The findings of this study add to the results of several studies, from meso- to eutrophic 444 environments, showing that bivalve growth is dependent on food availability, albeit in a 445 manner that is often poorly understood(Coe 1945, Winter 1978, Widdows et al. 1979, 446 Bayne \& Newell 1983, Frechette \& Bourget 1985, Macdonald \& Thompson 1985, Soniat 447 \& Ray 1985, Berg \& Newell 1986, Page \& Hubbard 1987, Gibbs et al. 1991, Hickman et 448 al. 1991, Grant 1996, Hawkins et al. 1999, Karayucel et al. 2003). Apparently the 449 cumulative tissue growth over the sampling period was more affected by phytoplankton 450 concentration compared to shell growth, as only minor- or non-differences in mussel 451 shell length were detected between the upwelling and control site(Figs. 5 and 7). The lack 452 of correlation between the seston parameters and shell growth also indicates that growth 453 in shell length is largely independent of the range of food concentration studied. These

454 findings support the previous conclusion that the seasonal growth in shell and tissue is 455 uncoupled (Hilbish 1986), that the internal shell volume does not restrain tissue growth 456 (Palmer 1981), and that a lesser fraction of the surplus energy (20-30\%) is allocated to 457 shell growth (Hawkins \& Bayne 1992, Duarte et al. 2010). However, following Dynamic 458 Energy Budget theory (Kooijman 2010), tissue weight is divided into structural tissue and 459 reproductive tissue. Of these only the structural weight should be compared to shell 460 length. We did not dissect the mussel in these components. Yet, assuming that all 
461 reproductive tissue is lost during spawning, then Fig. 7 indicate that the structural weight

462 is rather similar at both locations and the differences in weight were related to the 463 changes in reproductive tissue. This opens for the structural weight to be closer related to 464 food availability than detected for the DFW in this study.

466 Regulation of tissue growth by suspension feeding bivalves is mainly achieved through 467 the control of food acquisition, by modifying clearance rate(Hawkins et al. 1999, Gardner 468 \& Thompson 2001, Hawkins et al. 2001, Cranford et al. 2005, Strohmeier et al. 2009). 469 An increase in both clearance-and respiration rates of the two-year-old mussels 470 corresponded with the pre- and post-spawning periods in June, when growth rates were 471 highest.Clearance rates, averaged across the study period, were significantly lower in 472 mussels held under the enhanced dietary conditions at the upwelling site. The clearance 473 rates reported herein were similar to values previously reported for M. edulis under low474 seston conditions (Strohmeier et al. 2009), but higher food concentrations were also 475 encountered in the present study and the clearance rates of mussels tended to decrease at 476 these levels. Seston concentration typically has a strong influence on bivalve clearance 477 rate,with many species having been observed to decrease clearance rate with increasing 478 food quantity (reviewed by Cranford et al. 2011). This allows food intake to be 479 maximized during periods of low availability (Bayne et al. 1987). Our results indicate 480 that increased reproductive growth was achieved by increasing clearance rate, which 481 apparently more than compensated for the increased energy demand of reproduction that 482 was indicated by the increased respiration rate. The longer-term increase in tissue growth 483 at the upwelling site was achieved despite a decrease in clearance rate, simply due to 484 greater food concentration. This is demonstrated by the $40 \%$ higher ingestion rate at the 485 upwelling site(data not shown). Although mussel growth is highly sensitive to changes in 486 food absorption efficiency, the similar seston quality observed at both study sites (Table 487 1)would result in a similar absorption efficiency (Vahl 1980, Bayne et al. 1987, Cranford 488 1995, Cranford et al. 1998, MacDonald et al. 1998).

490 This study shows that increased phytoplankton concentrations in oligotrophic fjords may 491 be achieved by controlled upwelling of nutrient-rich deep water and that this results in 


\section{Growth of Mytilus edulis}

492 increased mussel tissue growth. Although mussels held in the upwelling region lose more 493 tissue mass during spawning, they also rebuild reproductive tissue faster, compared to 494 mussels kept at naturally-low seston concentrations. The main consequence of enhanced 495 food conditions for mussel cultivation is the potential for higher meat yields from a given 496 area of fjord during the production season. The increased primary production and bivalve 497 production carrying capacity of controlled upwelling systems in oligotrophic 498 environments will allow increased stocking density and thereby reduce the area required 499 for human food production.

\section{Acknowledgements}

502 This project was funded by the Research Council of Norway (Project No 196560). The 503 authors would like to thank Cathinka Krogness for assisting in the experimental work.

504 The experiments comply with the current laws of the country in which the experiments 505 have been conducted. 
Growth of Mytilus edulis

\section{References}

Alvarez-Salgado XA, Labarta U, Fernandez-Reiriz MJ, Figueiras FG, Roson G, Piedracoba S, Filgueira R, Cabanas JM (2008) Renewal time and the impact of harmful algal blooms on the extensive mussel raft culture of the Iberian coastal upwelling system (SW Europe). Harmful Algae 7:849-855

Andersen S, Strohmeier T, Strand HK, Strand O (2014) Karbonfangst og matproduksjon i fjorder. Rapport fra Havforskningen Book 7

Aure J, Strand O, Erga SR, Strohmeier T (2007a) Primary production enhancement by artificial upwelling in a western Norwegian fjord. Mar Ecol-Prog Ser 352:39-52

Aure J, Strand $\varnothing$, Skaar A (2001) Framtidige muligheter for havbruk i Lysefjorden. Fisken og havet, Book 2001. Havforskningsinstituttet, Bergen

Aure J, Strohmeier T, Strand O (2007b) Modelling current speed and carrying capacity in long-line blue mussel (Mytilus edulis) farms. Aquaculture Research 38:304-312

Bayne BL (1998) The physiology of suspension feeding by bivalve molluscs: an introduction to the Plymouth "TROPHEE" workshop. J Exp Mar Biol Ecol 219:119

Bayne BL (2001) Comment - Physiological regulation versus autonomous filtration in filter-feeding bivalves: Starting points for progress - Reply to comment by H.U. Riisgard. Ophelia 54:211-211

Bayne BL, Hawkins AJS, Navarro E (1987) Feeding and digestion by the mussel Mytilus edulis L (Bivalvia-Mollusca) in mixtures of silt and algal cells at low concetrations. J Exp Mar Biol Ecol 111:1-22

Bayne CJ, Newell RC (1983) Physiological energetics of marine molluscs. In: Saleuddin ASM, Wilbur KM (eds) The Mollusca, Physiology, Part 1, Book 4. Academic Press, New York

Berg JA, Newell RIE (1986) Temporal and spatial variations in the composition of seston available to the suspension feeder Crassostrea virginica. Estuarine Coastal Shelf Sci 23:375-386

Coe WR (1945) Nutrition and growth of the california bay-mussel (Mytilus edulis diegensis). J Exp Zoo 99:1-14

Cranford PJ (1995) Relationships between food quantity and quality and absorption efficiency in sea scallops Placopecten magellanicus (Gmelin). J Exp Mar Biol Ecol 189:123-142

Cranford PJ (2001) Evaluating the 'reliability' of filtration rate measurements in bivalves. Marine Ecology Progress Series 215:303-305

Cranford PJ, Annsworthy SL, Mikkelsen OA, Milligan TG (2005) Food acquisition responses of the suspension-feeding bivalve Placopecten magellanicus to the flocculation and settlement of a phytoplankton bloom. J Exp Mar Biol Ecol 326:128-143

Cranford PJ, Emerson CW, Hargrave BT, Milligan TG (1998) In situ feeding and absorption responses of sea scallops Placopecten magellanicus (Gmelin) to storm-induced changes in the quantity and composition of the seston. J Exp Mar Biol Ecol 219:45-70

Cranford PJ, Hill PS (1999) Seasonal variation in food utilization by the suspensionfeeding bivalve molluscs Mytilus edulis and Placopecten magellanicus. Mar EcolProg Ser 190:223-239 
Growth of Mytilus edulis

552

553

554

555

556

557

558

559

560

561

562

563

564

565

566

567

568

569

570

571

572

573

574

575

576

577

578

579

580

581

582

583

584

585

586

587

588

589

590

591

592

593

594

595

596

Cranford PJ, Ward JE, Shumway SE (2011) Bivalve Filter Feeding: Variability and Limits of the Aquaculture Biofilter. Shellfish Aquaculture and the Environment. Wiley-Blackwell

Duarte P, Fernandez-Reiriz MJ, Filgueira R, Labarta U (2010) Modelling mussel growth in ecosystems with low suspended matter loads. J Sea Res 64:273-286

Erga SR (1989a) Ecological-studies on the phytoplankton of Boknafjorden, Western Norway. 1. The effect of water exchange processes and environmental-factors on temporal and vertical variability of biomass. Sarsia 74:161-176

Erga SR (1989b) Ecological-studies on the phytoplankton of Boknafjorden, Western Norway. 2. Environmental-control of photosynthesis. J Plankton Res 11:785-812

Erga SR, Aursland K, Frette O, Hamre B, Lotsberg JK, Stamnes JJ, Aure J, Rey F, Stamnes K (2005) UV transmission in Norwegian marine waters: controlling factors and possible effects on primary production and vertical distribution of phytoplankton. Mar Ecol-Prog Ser 305:79-100

Erga SR, Heimdal BR (1984) Ecological-studies on the phytoplankton of Korsfjorden, Western Norway - the dynamics of a spring bloom seen in relation to hydrographical conditions and light regime. J Plankton Res 6:67-90

Erga SR, Skjoldal HR (1990) Diel variations in photosynthetic activity of summer phytoplankton in Lindaspollene, Western Norway. Mar Ecol-Prog Ser 65:73-85

Erga SR, Ssebiyonga N, Frette O, Hamre B, Aure J, Strand O, Strohmeier T (2012) Dynamics of phytoplankton distribution and photosynthetic capacity in a western Norwegian fjord during coastal upwelling: Effects on optical properties. Estuarine Coastal Shelf Sci 97:91-103

Figueiras FG, Labarta U, Reiriz MJF (2002) Coastal upwelling, primary production and mussel growth in the Rias Baixas of Galicia. Hydrobiologia 484:121-131

Filgueira R, Grant J, Strand O, Asplin L, Aure J (2010) A simulation model of carrying capacity for mussel culture in a Norwegian fjord: Role of induced upwelling. Aquaculture 308:20-27

Filgueira R, Labarta U, Fernandez-Reiriz MJ (2008) Effect of condition index on allometric relationships of clearance rate in Mytilus galloprovincialis Lamarck, 1819. Rev Biol Mar Oceanogr 43:391-398

Frechette M, Bourget E (1985) Food-limited growth of Mytilus edulis L in relation to the benthic boundary-layer. Can J Fish Aquat Sci 42:1166-1170

Gardner JPA, Thompson RJ (2001) Naturally low seston concentration and the net energy balance of the greenshell mussel (Perna canaliculus) at Island Bay, Cook Strait, New Zealand. N Z J Mar Freshwater Res 35:457-468

Gibbs MM, James MR, Pickmere SE, Woods PH, Shakespeare BS, Hickman RW, Illingworth J (1991) Hydrodynamic and water column properties at 6 stations associated with mussel farming in Pelorus Sound, 1984-85. New Zealand Journal of Marine and Freshwater Research 25:239-254

Grant J (1996) The relationship of bioenergetics and the environment to the field growth of cultured bivalves. J Exp Mar Biol Ecol 200:239-256

Hawkins AJS, Bayne CJ (1992) Physiological interrelations and the regulation of production. In: Gosling EM (ed) The mussel Mytilus: Ecology, Physiology, Genetics and Culture. Elsevier, Amsterdam 
Growth of Mytilus edulis

597

598

599

600

601

602

603

604

605

606

607

608

609

610

611

612

613

614

615

616

617

618

619

620

621

622

623

624

625

626

627

628

629

630

631

632

633

634

635

636

637

638

639

640

641

Hawkins AJS, Fang JG, Pascoe PL, Zhang JH, Zhang XL, Zhu MY (2001) Modelling short-term responsive adjustments in particle clearance rate among bivalve suspension-feeders: separate unimodal effects of seston volume and composition in the scallop Chlamys farreri. J Exp Mar Biol Ecol 262:61-73

Hawkins AJS, James MR, Hickman RW, Hatton S, Weatherhead M (1999) Modelling of suspension-feeding and growth in the green-lipped mussel Perna canaliculus exposed to natural and experimental variations of seston availability in the Marlborough Sounds, New Zealand. Mar Ecol-Prog Ser 191:217-232

Hickman RW, Waite RP, Illingworth J, Meredythyoung JL, Payne G (1991) The relationship between farmed mussels, Perna canaliculus, and available food in Pelorus-Kenepuru sound, New Zealand, 1983-1985. Aquaculture 99:49-68

Hilbish TJ (1986) Growth trajectories of shell and soft tissue in bivalves: Seasonal variation in Mytilus edulis L. J Exp Mar Biol Ecol 96:103-113

Jeong YK, Lee HN, Park CI, Kim DS, Kim MC (2013) Variation of phytoplankton and zooplankton communities in a sea area, with the building of an artificial upwelling structure. Animal Cells and Systems 17:63-72

Jones HD, Richards OG, Southern TA (1992) Gill dimensions, water pumping rate and body size in the mussel Mytilus edulis-L. J Exp Mar Biol Ecol 155:213-237

Karayucel S, Karayucel I, Erdem M, Saygun S, Uyan O (2003) Growth and production in long-line cultivated Mediterranean mussel (Mylitus galloprovincialis) in Sinop, Black Sea. Israeli J Aquaculture-Bamidgeh 55:169-178

Kooijman S (2010) Dynamic Energy Budget Theory for Metabolic Organistion. Cambridge University Press, Cambridge

Latour SA, Miniard PW (1983) The misuse of repeated measures analysis in marketingresearch. J Mark Res 20:45-57

MacDonald BA, Bacon GS, Ward JE (1998) Physiological responses of infaunal (Mya arenaria) and epifaunal (Placopecten magellanicus) bivalves to variations in the concentration and quality of suspended particles II. Absorption efficiency and scope for growth. J Exp Mar Biol Ecol 219:127-141

Macdonald BA, Thompson RJ (1985) Influence of temperature and food availability on the ecological energetics of the giant scallop Placopecten magellanicus. 1. Growth-rates of shell and somatic tissue. Mar Ecol-Prog Ser 25:279-294

Paasche E, Erga SR (1988) Phosphorus and nitrogen limitation of phytoplankton in the inner Oslofjord (Norway). Sarsia 73:229-243

Page HM, Hubbard DM (1987) Temporal and spatial patterns of growth in mussels Mytilus edulis on an offshore platform - relationships to water temperature and food availability. J Exp Mar Biol Ecol 111:159-179

Palmer RA (1981) Do carbonate skeletons limit the rate of body growth? Nature 292:150-152

Pitcher GC, Calder D (1998) Shellfish mariculture in the Benguela system: Phytoplankton and the availability of food for commercial mussel farms in Saldanha Bay, South Africa. J Shellfish Res 17:15-24

Pouvreau S, Jonquieres G, Buestel D (1999) Filtration by the pearl oyster, Pinctada margaritifera, under conditions of low seston load and small particle size in a tropical lagoon habitat. Aquaculture 176:295-314 
Growth of Mytilus edulis

642

643

644

645

646

647

648

649

650

651

652

653

654

655

656

657

658

659

660

661

662

663

664

665

666

667

668

669

670

671

672

673

674

675

676

677

678

679

680

681

682

683

684

685

686
Riisgard HU (2001) The stony road to reliable filtration rate measurements in bivalves: a reply. Mar Ecol-Prog Ser 215:307-310

Riisgard HU, Pleissner D, Lundgreen K, Larsen PS (2013) Growth of mussels Mytilus edulis at algal (Rhodomonas salina) concentrations below and above saturation levels for reduced filtration rate. Mar Biol Res 9:1005-1017

Rosland R, Bacher C, Strand O, Aure J, Strohmeier T (2011) Modelling growth variability in longline mussel farms as a function of stocking density and farm design. J Sea Res 66:318-330

Rosland R, Strand O, Alunno-Bruscia M, Bacher C, Strohmeier T (2009) Applying Dynamic Energy Budget (DEB) theory to simulate growth and bio-energetics of blue mussels under low seston conditions. J Sea Res 62:49-61

Sara G, Pusceddu A (2008) Scope for growth of Mytilus galloprovincialis (Lmk., 1819) in oligotrophic coastal waters (Southern Tyrrhenian Sea, Italy). Mar Biol 156:117-126

Saxby SA (2002) A review of food availability, sea water charateristics and bivalve growth performance at coastal culture sites in temperate and warm regions of the world. Fisheries research report, Book 132. Department of Fisheries, Western Australia

Smaal AC, Vonck A, Bakker M (1997) Seasonal variation in physiological energetics of Mytilus edulis and Cerastoderma edule of different size classes. J Mar Biol Assoc U K 77:817-838

Soniat TM, Ray SM (1985) Relationships between possible available food and the composition, condition and reproductive state of oyster from Galveston Bay, Texas. Contributions in Marine Science 28:109-121

Strickland JDH, Parson TR (1968) A practical handbook of seawater analysis. Bull Fish Res Can 167:1-311

Strohmeier T (2009) Feeding behavior and bioenergetic balance of the great scallop (Pecten maximus) and the mussel (Mytilus edulis) in a low seston environment and relevance to suspenmded shellfish aquaculture. Philosophiae doctor $\mathrm{PhD}$, University of Bergen, Norway, Bergen

Strohmeier T, Aure J, Duinker A, Castberg T, Svardal A, Strand O (2005) Flow reduction, seston depletion, meat content and distribution of diarrhetic shellfish toxins in a long-line blue mussel (Mytilus edulis) farm. J Shellfish Res 24:15-23

Strohmeier T, Duinker A, Strand O, Aure J (2008) Temporal and spatial variation in food availability and meat ratio in a longline mussel farm (Mytilus edulis). Aquaculture 276:83-90

Strohmeier T, Strand Ø, Alunno-Bruscia M, Duinker A, Cranford PJ (2012) Variability in particle retention efficiency by the mussel Mytilus edulis. J Exp Mar Biol Ecol 412:96-102

Strohmeier T, Strand O, Cranford P (2009) Clearance rates of the great scallop (Pecten maximus) and blue mussel (Mytilus edulis) at low natural seston concentrations. Mar Biol 156:1781-1795

Vahl O (1980) Seasonal-variations in seston and in the growth-rate of the iceland scallop, Chlamys islandica (Muller, O.F.) from Balsfjord, 70-degrees-n. J Exp Mar Biol Ecol 48:195-204 
Ward JE, Shumway SE (2004) Separating the grain from the chaff: particle selection in suspension- and deposit-feeding bivalves. J Exp Mar Biol Ecol 300:83-130

Widdows J (2001) Bivalve clearance rates: inaccurate measurements or inaccurate reviews and misrepresentation? Marine Ecology Progress Series 221:303-305

Widdows J, Fieth P, Worrall CM (1979) Relationships between seston, available food and feeding-activity in the common mussel Mytilus edulis. Mar Biol 50:195-207

Winter JE (1978) Review of knowledge of suspension-feeding in lamellibranchiate bivalves, with special reference to artificial aquaculture systems. Aquaculture 13:1-33

Yanagi T, Nakajima M (1991) Change of oceanic condition by the man-made structure for upwelling. Mar Pollut Bull 23:131-135

Yukihira H, Klumpp DW, Lucas JS (1999) Feeding adaptations of the pearl oysters Pinctada margaritifera and P-maxima to variations in natural particulates. Mar Ecol-Prog Ser 182:161-173

Zar JH (1996) Biostatistical analysis. Prentice Hall, Upper Saddle River 
Growth of Mytilus edulis

704

705

706

707

708

709

710

711

\section{2}

713

714

715

716

717

718

719

720

Table 1. Mean values $( \pm$ SD) of seston quantity and quality indicators at7 $\mathrm{m}$ depth at the upwelling (UPW) and control (CONTR) stations during May $6^{\text {th }}$ to August $11^{\text {th }} 2010$. Mean chlorophyll $a$ values are calculated from in situ fluorometer (fChl $a$ ) and discrete water sample (wChl $a$ ) data. PV is the particle volume concentration, SPM is suspended particulate matter, POC is particulate organic carbon, $\mathrm{POM} \%$ is the organic content of SPM and C:N is the molar carbon to nitrogen ratio.

\begin{tabular}{cccccccc} 
Site & $\begin{array}{c}\mathrm{fChl} a \\
\left(\mathrm{mg} \mathrm{m}^{-3}\right)\end{array}$ & $\begin{array}{c}\text { wChl } a \\
\left(\mathrm{mg} \mathrm{m}^{-3}\right)\end{array}$ & $\begin{array}{c}\mathrm{PV} \\
\left(\mathrm{ml} \mathrm{m}^{-3}\right)\end{array}$ & $\begin{array}{c}\mathrm{SPM} \\
\left(\mathrm{mg} \mathrm{m}^{-3}\right)\end{array}$ & $\begin{array}{c}\mathrm{POC} \\
\left(\mathrm{mg} \mathrm{m}^{-3}\right)\end{array}$ & $\begin{array}{c}\text { POM\% } \\
(\%)\end{array}$ & C:N \\
\hline UPW & $2.9(1.8)$ & $3.3(1.9)$ & $4.0(3.1)$ & $3.1(1.2)$ & $302(198)$ & 54 & 5.9 \\
CONTR & $1.4(0.4)$ & $1.5(0.6)$ & $2.5(1.4)$ & $2.5(1.2)$ & $239(128)$ & 59 & 7.0 \\
\hline
\end{tabular}

Table 2.Summary of results from repeated measures ANOVA comparisons of site (upwelling vs. control Lysefjord locations) effects on the mean shell length (SL), and standardized clearance $(C)$ and respiration rates $(R)$ of two mussel cohorts. Separate test results are shown for the indicated mussel cohort and significant mean effects $\left(^{*}=p \leq\right.$ $0.05 ; * *=p \leq 0.01$; and $* * *=p \leq 0.001)$ and adequate statistical power at $\alpha=0.05$ (*; 1 $\beta \geq 0.8)$ are indicated.

\begin{tabular}{lcccccc} 
Parameter (Cohort) & SS & $\begin{array}{c}\text { Degr. Of } \\
\text { Freedom }\end{array}$ & MS & F & $P$ & $1-\beta$ \\
\hline Shell Length (2008) & & & & & & \\
\hline Intercept & 1485174 & 1 & 1485174 & 419475 & $<0.001^{* * *}$ & $1.000^{*}$ \\
Samp. Date & 1082 & 11 & 98 & 28 & $<0.001^{* * *}$ & $1.000^{*}$ \\
SL * site & 303 & 1 & 303 & 104 & $<0.001^{* * *}$ & $1.000^{*}$ \\
SL S. Date & 171 & 11 & 16 & 5.4 & $<0.001^{* * *}$ & $1.000^{*}$ \\
Shell Length (2009) & & & & & & \\
\hline Intercept & 485303 & 1 & 485303 & 33255 & $<0.001^{* * *}$ & $1.000^{*}$ \\
Samp. Date & 14064 & 11 & 1279 & 88 & $<0.001^{* * *}$ & $1.000^{*}$ \\
SL & 20 & 1 & 20 & 1.8 & 0.179 & $0.269^{*}$ \\
SL $*$ S. Date & 15 & 11 & 1.4 & 0.1 & 0.999 & $0.092^{*}$ \\
$\boldsymbol{C}(\mathbf{2 0 0 8})$ & & & & & & \\
\hline Intercept & 2727 & 1 & 2727 & 855 & $<0.001^{* * *}$ & $1.000^{*}$ \\
Sample Date & 145 & 6 & 24 & 8 & $<0.001^{* * *}$ & $0.999^{*}$ \\
$C$ & 38 & 1 & 38 & 21 & $<0.001^{* * *}$ & $0.996^{*}$ \\
$C *$ Date & 173 & 6 & 29 & 21 & $<0.001^{* * *}$ & $1.000^{*}$ \\
$\boldsymbol{R}(\mathbf{2 0 0 8})$ & 124 & 1 & 124 & 2657 & $<0.001^{* * *}$ & $1.000^{*}$ \\
\hline Intercept & 6.2 & 6 & 1.03 & 22 & $<0.001^{* * *}$ & $1.000^{*}$ \\
Sample Date & 0.00 & 1 & 0.00 & 0.04 & 0.84 & 0.055 \\
$R$ & 0.88 & 6 & 0.15 & 2.60 & $<0.026^{*}$ & $0.815^{*}$ \\
\hline$*$ Date & & & & & & \\
\hline & & & & &
\end{tabular}


Growth of Mytilus edulis

721

722 


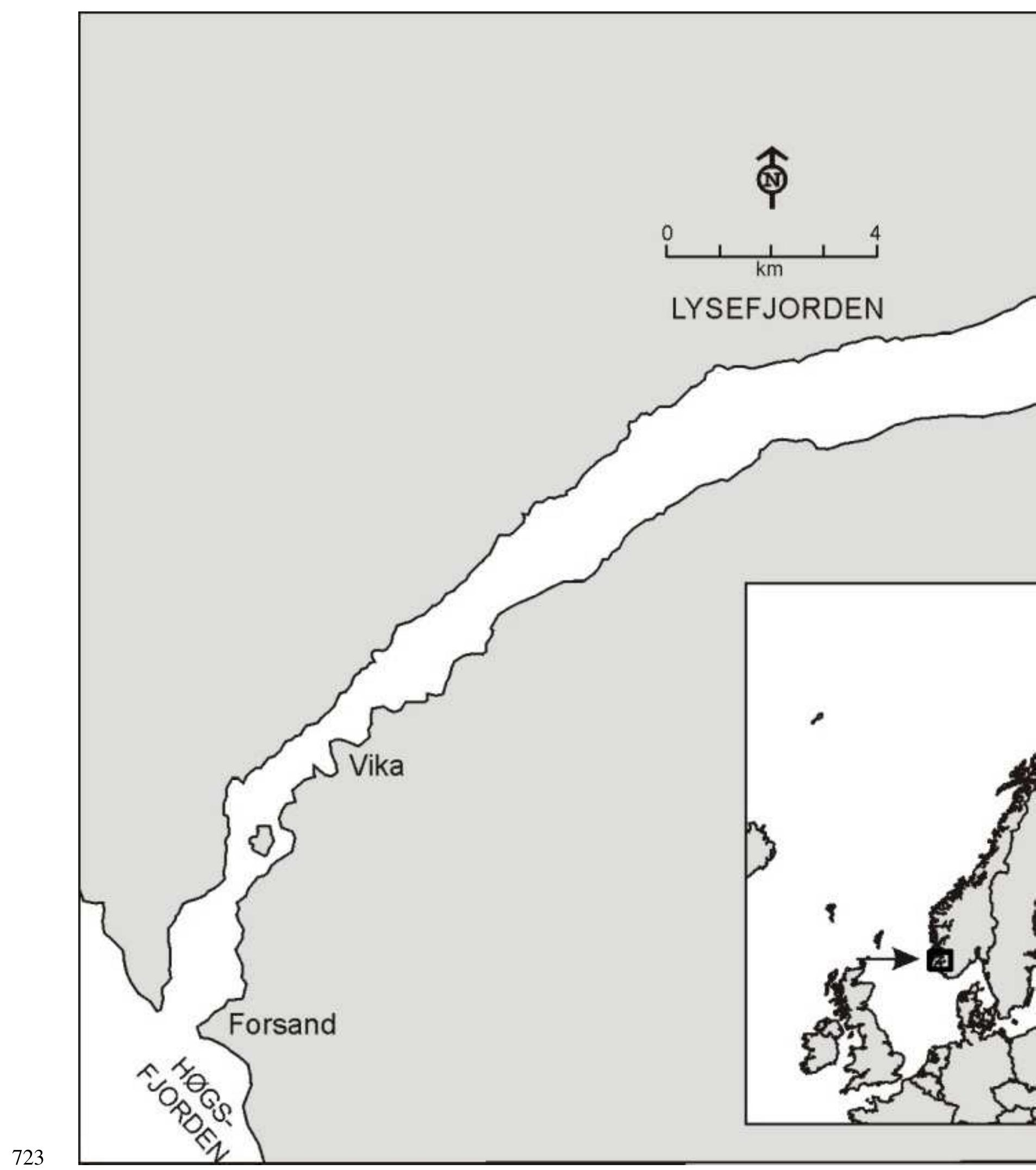




\section{Growth of Mytilus edulis}

724 Figure 1. Map of North-Western Europe (insert), South-Western Norway (insert) and 725 Lysefjord indicating the experimental sites, where Upw represents the upwelling station 726 and Ctrl represents the control station.
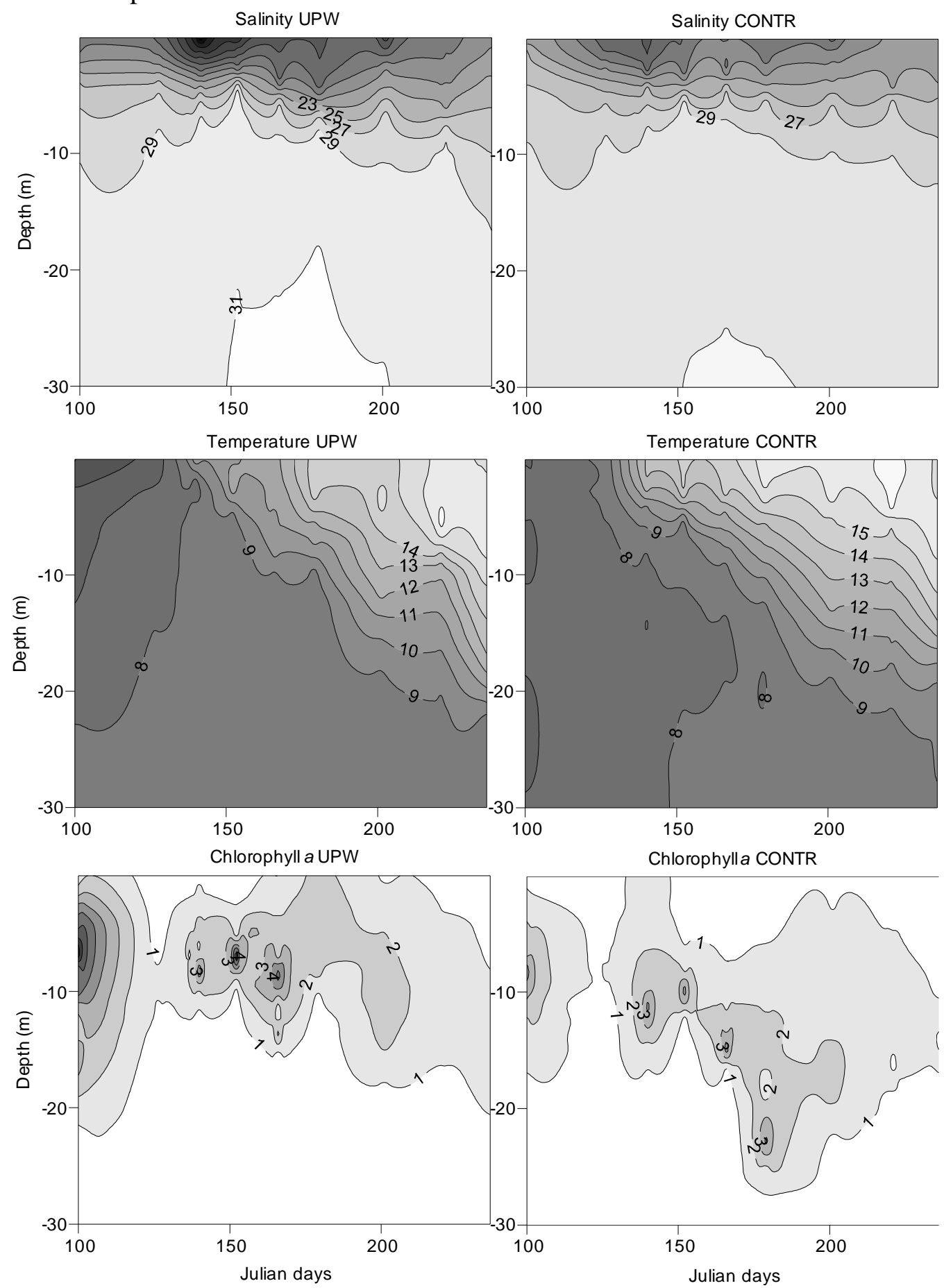

727 Figure 2. Time series of salinity, temperature and estimated chlorophyll $a$ at the 729 upwelling station (UPW) and control station from the $10^{\text {th }}$ of April to the $24^{\text {th }}$ of August in 730 the upper 30 $\mathrm{m}$ of the Lysefjord. 


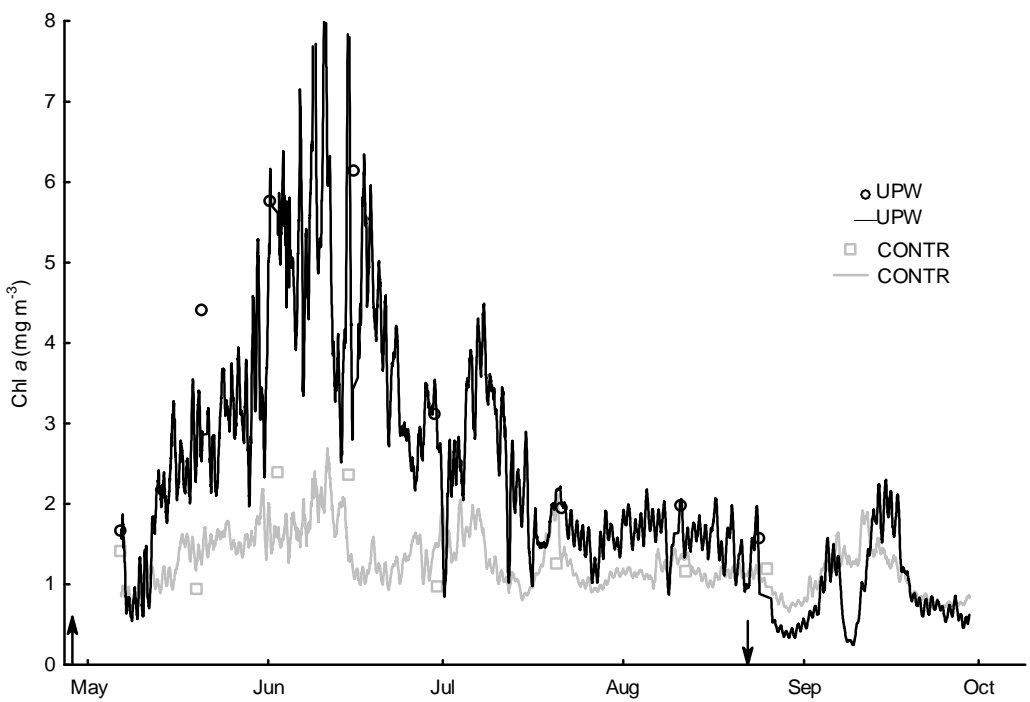

735 Figure 3. Time series of estimated chlorophyll $a$ (Chl $a$ ) from in situ flurometers (lines) 736 and from water samples (o and $\square$ ) at $7 \mathrm{~m}$ depth within the upwelling area (UPW) and at the control station (CONTR). In situ instrument measurements are presented on a daily basis (running mean of 24 hourly samples). Arrows on $\mathrm{x}$-axis indicate when the pump was started and shut down. 

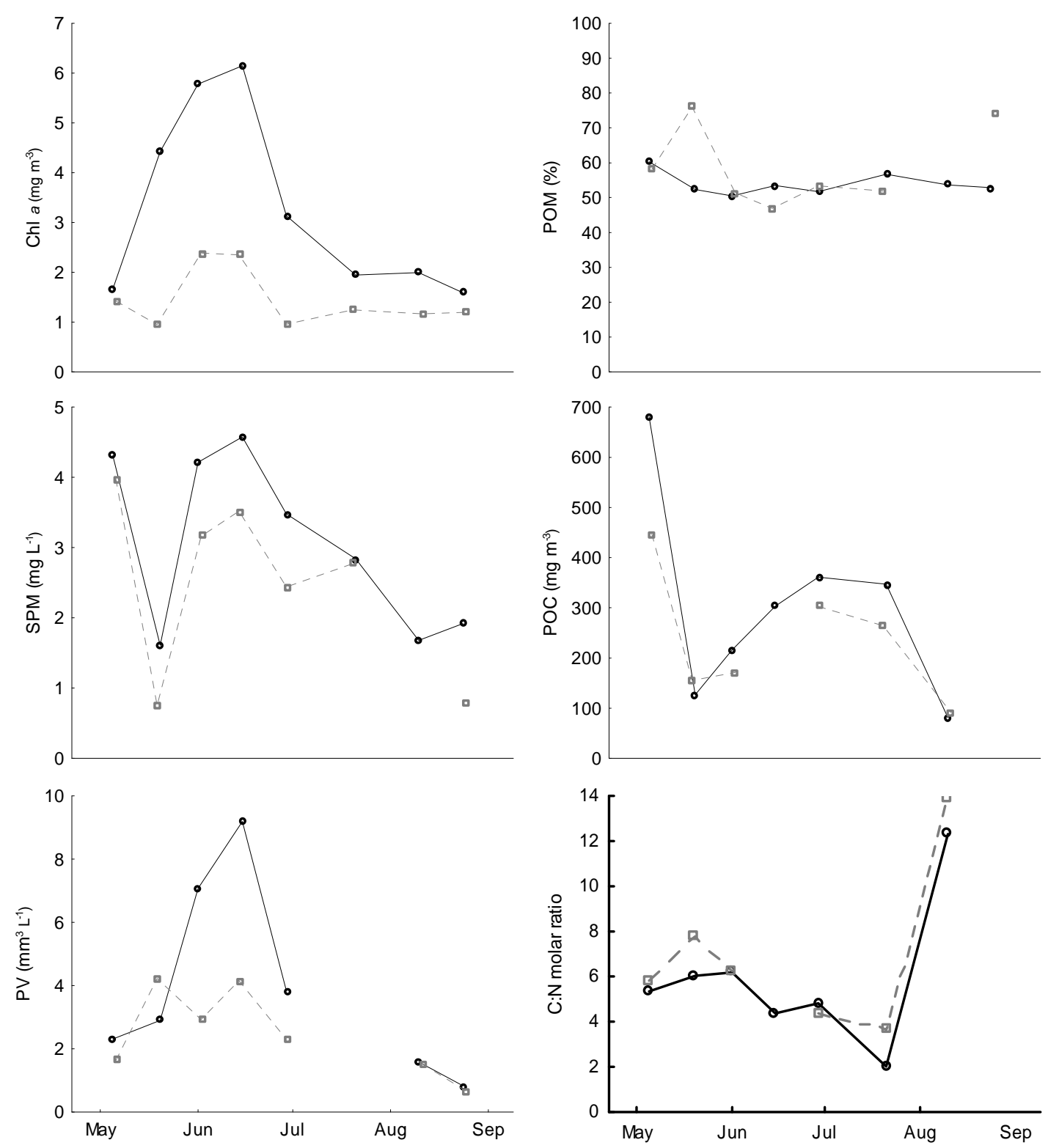

Figure 4. Time series of chlorophyll $a$ (Chl $a$, from water samples), mean particle 742 volume concentration (PV;total for 1-60 $\mu \mathrm{m}$ particles), particulate organic carbon (POC), 743 suspended particulate matter (SPM), organic matterfraction (POM\%) and the ratio of 744 carbon to nitrogen $(\mathrm{C}: \mathrm{N})$ at $7 \mathrm{~m}$ depth at upwelling (UPW, line) and control (CONTR 745 dotted line) stations.Missing data points due to lack of sampling (PV) and disrupted 746 filters (SPM and CN) 
Growth of Mytilus edulis

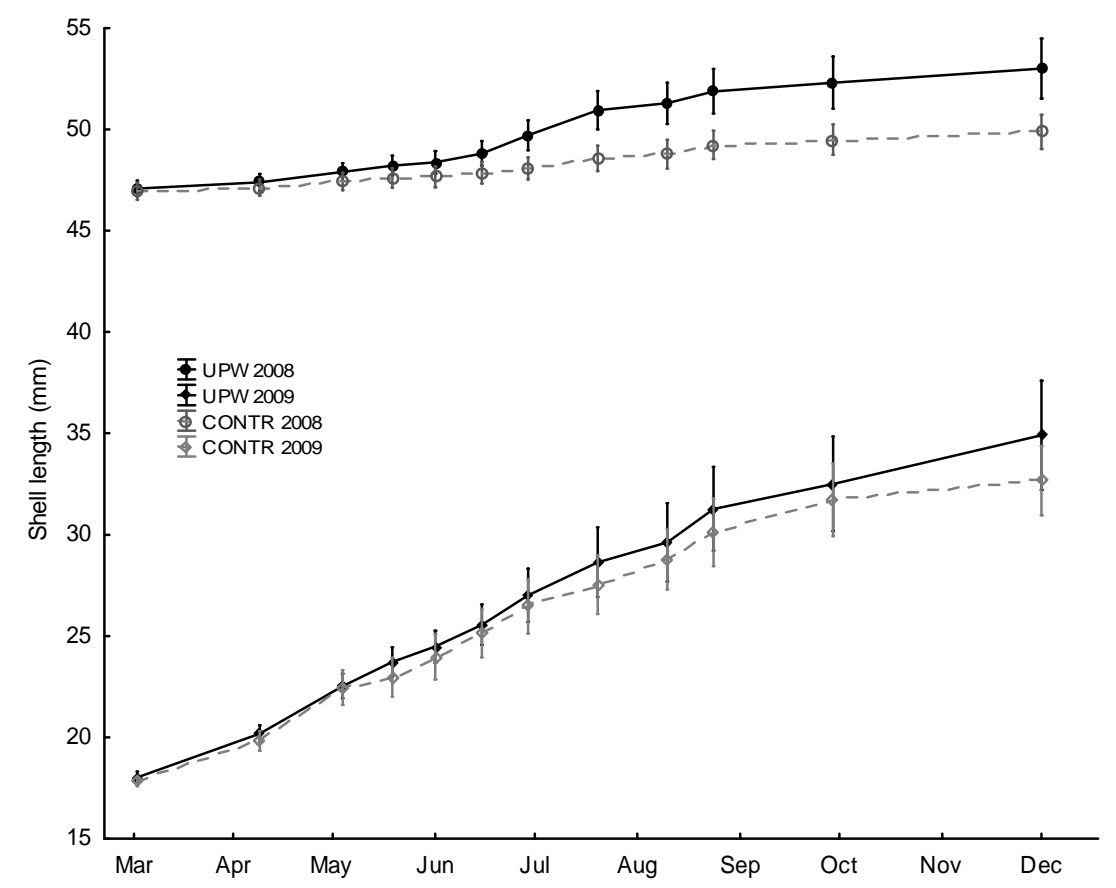

748 Figure 5. Temporal changes in mean shell length $(\mathrm{mm})$ for individually marked M. edulis 749 from two mussel cohorts (2008 and 2009) held at $7 \mathrm{~m}$ depth at the upwelling (UPW) and 750 control (CONTR) stations. Vertical lines indicate $\pm 95 \%$ confidence limits. 
Growth of Mytilus edulis

751
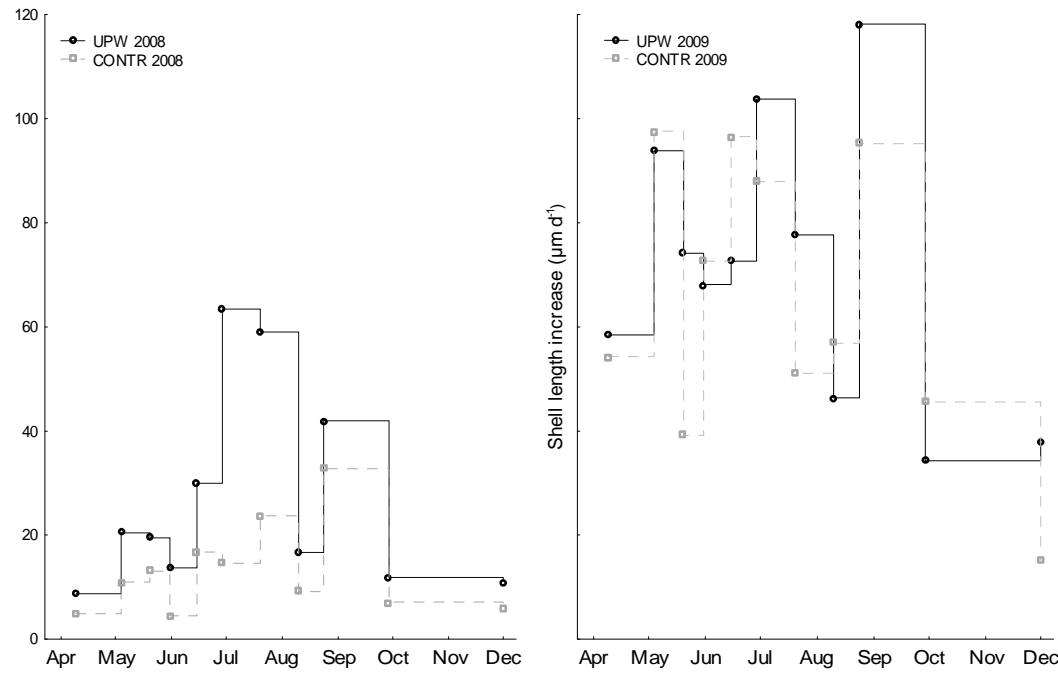

752

Figure 6. Temporal

753 changes in the mean daily growth of M. edulis shell $\left(\mu \mathrm{m} \mathrm{d}^{-1}\right)$, from two cohorts (2008 and 754 2009) held at $7 \mathrm{~m}$ depth at the upwelling (UPW) and control (CONTR) stations in 755 Lysefjord.

756 
756

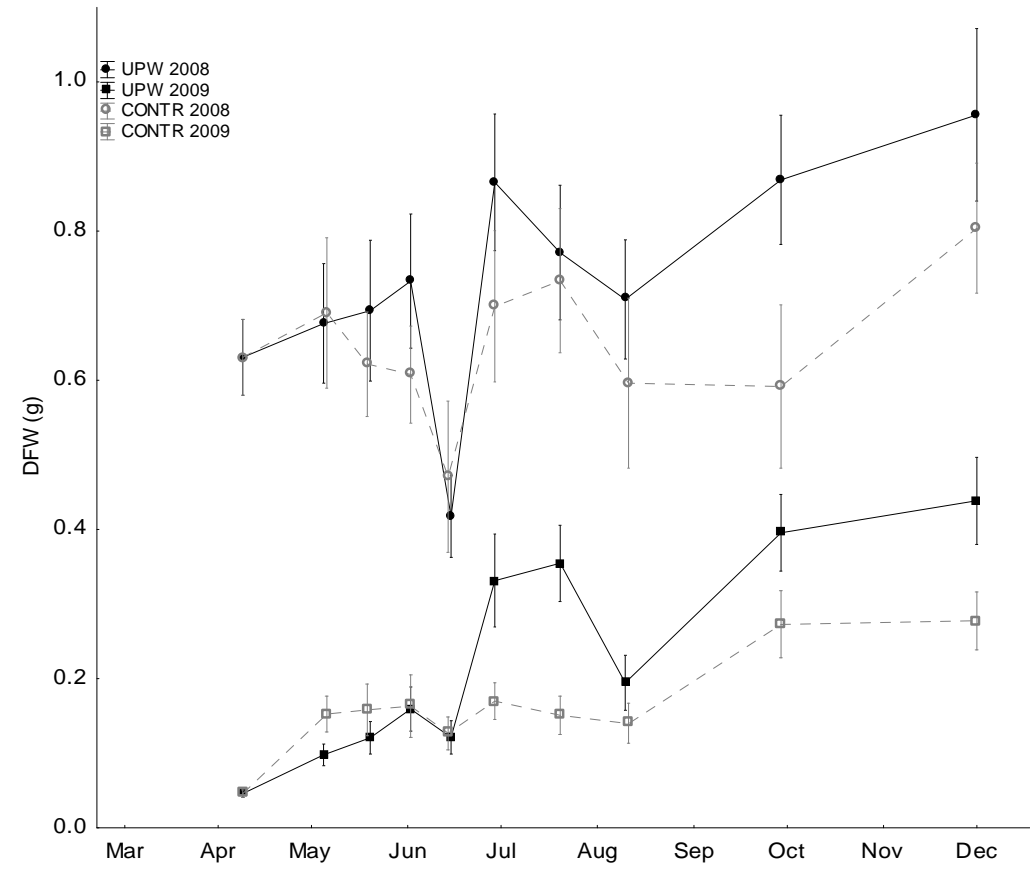

758 Figure 7. Temporal changes in mean dry flesh weight (DFW, g) oftwoM. eduliscohorts 759 (2008 and 2009) held at $7 \mathrm{~m}$ depth at the upwelling (UPW) and control (CONTR) 760 stations in Lysefjord from March 2010 to December 2010. Vertical lines indicate $\pm 95 \%$ 761 confidence limits. 
Growth of Mytilus edulis

762
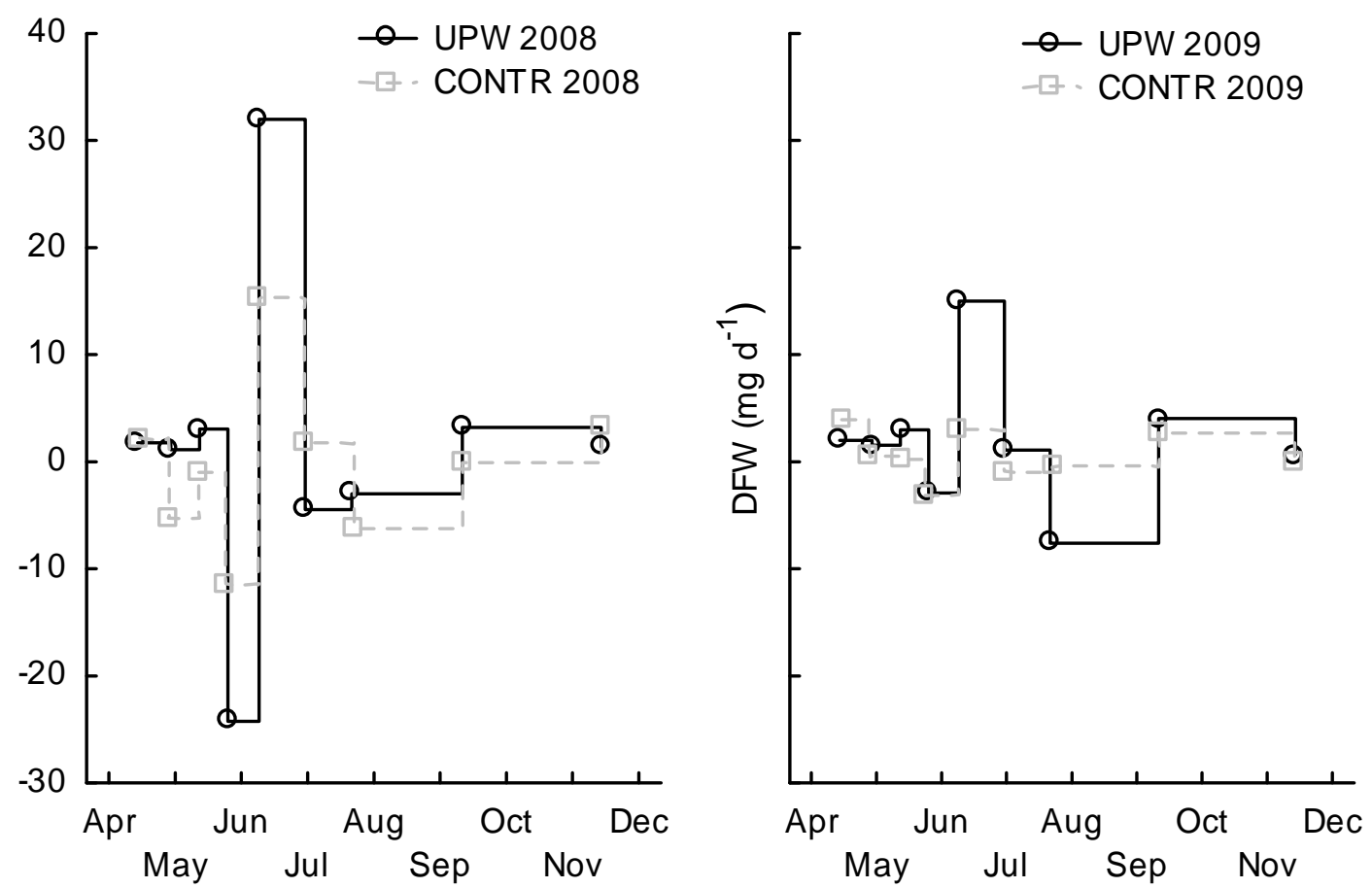

763

764 Figure 8. Temporal changes in estimated mean daily dry flesh growth rate (DFW; $\mathrm{mg} \mathrm{d}^{-}$ $765^{1}$ ) of two M. eduliscohorts (2008 and 2009) held at $7 \mathrm{~m}$ depth at the upwelling (UPW) and 766 (CONTR) stations in Lysefjord. 
Growth of Mytilus edulis

767

768

769
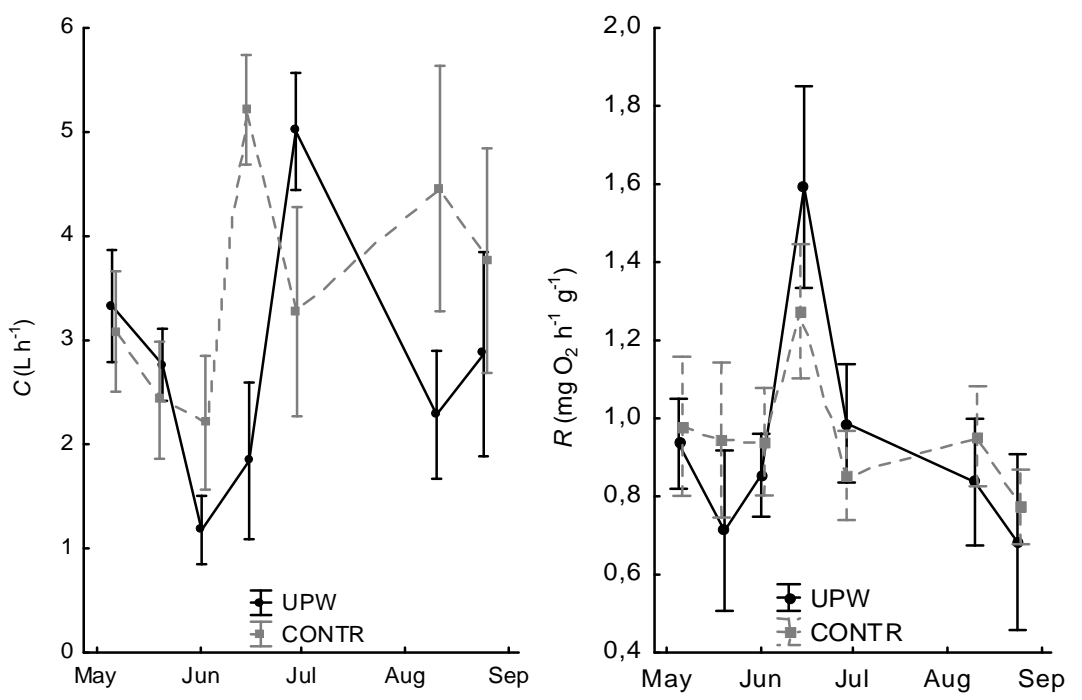

Figure 9.Temporal

771 changes in mean clearance rate standardized to a $50 \mathrm{~mm}$ shell length individual $\left(C ; \mathrm{L} \mathrm{h}^{-1}\right)$ 772 and dry flesh weight standardized respiration rate $\left(R ; \mathrm{mg} \mathrm{O}_{2} \mathrm{~h}^{-1} \mathrm{~g}^{-1}\right)$ for the 2008 cohorts 773 held at the upwelling (UPW) and control sites (CONTR) in Lysefjord. 